which is an accepted treatment for detrusor instability and that terodiline $25 \mathrm{mg}$ daily does not improve on its efficacy. The number of patients in the study, however, was small and may have been insufficient to detect a drug effect. We required very elderly, ambulant, and compliant patients for the trial to be confident of the accuracy of our outcome measures, and such patients are difficult to recruit.

Nevertheless it was a single centre study, and we recruited more patients than all other controlled trials of terodiline apart from one multicentre trial. ${ }^{8}$ We have found that multicentre studies conducted on elderly patients are particularly difficult to coordinate.

To detect a possible drug effect in a trial which includes bladder retraining 378 patients would be required (Kabi, United Kingdom, personal communication), which would be impracticable. Even though there was no significant difference between terodiline and placebo groups in frequency of micturition or incontinence episodes, any change might have achieved significance with more patients. The median improvements in micturition and incontinence are similar between treatment groups despite the fact that the terodiline group had, if anything, worse symptoms at run in and thus more potential for improvement. The upper end of the $95 \%$ confidence interval for the difference between the terodiline and placebo groups was around one micturition or incontinence episode during the day or per 24 hours. We therefore believe that even if terodiline with bladder retraining is better than placebo with bladder retraining the benefit is likely to be marginal.

Although the dose of terodiline was smaller than that recommended for younger patients and the incidence of side effects was lower than in other studies, $25 \mathrm{mg}$ daily is the recommended dose for elderly patients and produced steady state serum concentrations of the drug similar to those produced by larger doses in younger patients. ${ }^{34}$ Indeed, our patients' serum concentrations of the drug were higher than those in other terodiline studies. ${ }^{89}$ Because terodiline is a calcium channel blocker postural instability may develop in elderly patients given higher doses, and prescribing must be cautious. The half life of the drug in elderly patients is more than double that in younger patients, with a mean of about 130 hours, and this justifies a single dose regimen. ${ }^{3}$

The frequency of micturition did not change significantly in either group, perhaps because our patients recorded fairly mild urinary frequency. Nevertheless, their overall urinary symptoms were severe enough to warrant referral by general practitioners to an incontinence clinic or outpatient clinic. Patients may have underrecorded their urinary frequency, but this did at least apply to both groups throughout the study. Despite the fairly low run in values patients could have improved well above the level of the upper confidence interval.

In this type of study outcome is difficult to measure, but our experience in the incontinence clinic has shown that bladder diary charts remain the most reliable measure. Urodynamic parameters are often advocated as suitable objective measures, but several studies have shown that they correlate poorly with symptoms. ${ }^{910}$ More direct methods, such as weighing incontinence pads, pose major logistical problems. Ultimately what matters is how the patient perceives his or her condition, which is what is reflected in the charts.

In conclusion, we have not produced evidence to support the current belief that terodiline confers any additional benefit over bladder retraining in the treatment of detrusor instability in frail elderly patients.

This work was supported by Kabi, United Kingdom. We thank Brian Newman of University College, London, for statistical advice.

1 Rud T, Anderson KE, Boye N, Ulmsten U. Terodiline inhibition of human bladder contraction. Effects in vitro and in women with unstable bladders. ticta Pharmacologica et Toxicologica 1980;46(suppl 1):31-8.

2 Ulmsten U, Andersson KE. Drug treatment of the overactive detrusor. Acta Pharmacologica et Toxicologica 1980;46(suppl):7-10.

3 Hallen B, Magnusson A, Bogentoft S, Ekelund P. Single and multiple dose pharmacokinetics of terodiline in geriatric patients. Eur $\mathcal{f}$ Clin Pharmacol 1988;34:291-7.

4 Frewen WK. A reassessment of bladder training in detrusor dysfunction in the female. $B r \mathcal{F}$ Urol 1982;54:372-3.

5 Abrams P. Feneley R, Torrens M. Urodynamics. London: Springer-Verlag, 1983:110-2

6 Malone-Lee JG, Chapple CR. In: Coleridge-Smith PD, Scurr JE, eds. Medical applications of microcomputers. A critical reziew of the development of a software package for clinical urodynamics. London: Springer-Verlag, 1988:87-93.

7 Minitab Inc. Minitah release 7. Pennsylvania: Minitab Inc, 1989.

8 Peters DF. Terodiline in the treatment of urinary frequency and motor urge incontinence. A controlled multicentre trial. Scand $\mathcal{F}$ Urol Nephrol 1984;87: suppl : 21 - 33 .

9 Fischer-Rasmussen $W$. Evaluation of long-term safety and clinical benefit in women with urgency/urge incontinence. A multicentre study. Scand $\mathcal{F}$ Urol Wephrol 1984:87 (suppl:35:47.

10 Macfarlane J, Tolley D. The effect of terodiline on patients with detrusor instability. Scand f Urol Nephrol 1984;87 (suppl):51-4.

(Accepted 27 February 1991)

\title{
Munchausen's syndrome and abnormalities on magnetic resonance imaging of the brain
}

\author{
Service des Maladies du \\ Système Nerveux, Hôpital \\ Tenon, 75970 Paris Cedex \\ 20, France \\ Gilles Fénelon, MD, \\ neurologist \\ Florence Mahieux, MD, \\ neurologist \\ Alain Guillard, MD, professor \\ of neurology
}

\section{Service de Neurologie, Hôpital St Antoine, Paris \\ Etienne Roullet, MD,} neurologist

\section{Gilles Fénelon, Florence Mahieux, Etienne Roullet, Alain Guillard}

The possibility of "a real organic lesion from the past" in Munchausen's syndrome was pointed out by Asher in his classic article.' Cerebral damage was later mentioned in a few cases, and Barker suggested that it might provide an organic basis for the syndrome. ${ }^{2} \mathrm{We}$ report a typical case of Munchausen's syndrome in which magnetic resonance imaging of the brain showed abnormalities.

\section{Case report}

A 35 year old man was admitted to several hospitals in Paris on at least 13 occasions between July 1986 and
June 1988 under eight known identities. He allegedly had been treated for appendicular peritonitis, inguinal hernia, spontaneous or traumatic pneumothorax, or gastric or duodenal ulcer. He also gave a history of cataract, detached retina, or glaucoma and of alcoholism, cardiac arrhythmia, urinary infection, epilepsy, and diabetes and claimed an allergy to iodine preparations. He recounted a life full of various tragic events concerning his mother, children, and wife; he was evasive about other relatives and friends and gave different names of general practitioners, which were not in professional registers.

In most documented cases the patient presented to the emergency room, saying that he had just experienced a generalised seizure or a hypoglycaemic episode. Sometimes a "weakness" of the left arm and leg persisted for a few days, but neurological examination otherwise yielded normal results. He was once caught rubbing the thermometer to raise the temperature. On several occasions he asked for his "usual" treatment, either oral hypoglycaemic drugs or insulin (he would give the insulin's proprietary name and dose). Genuine hypoglycaemia ensued several times, but investigations failed to confirm diabetes. During 

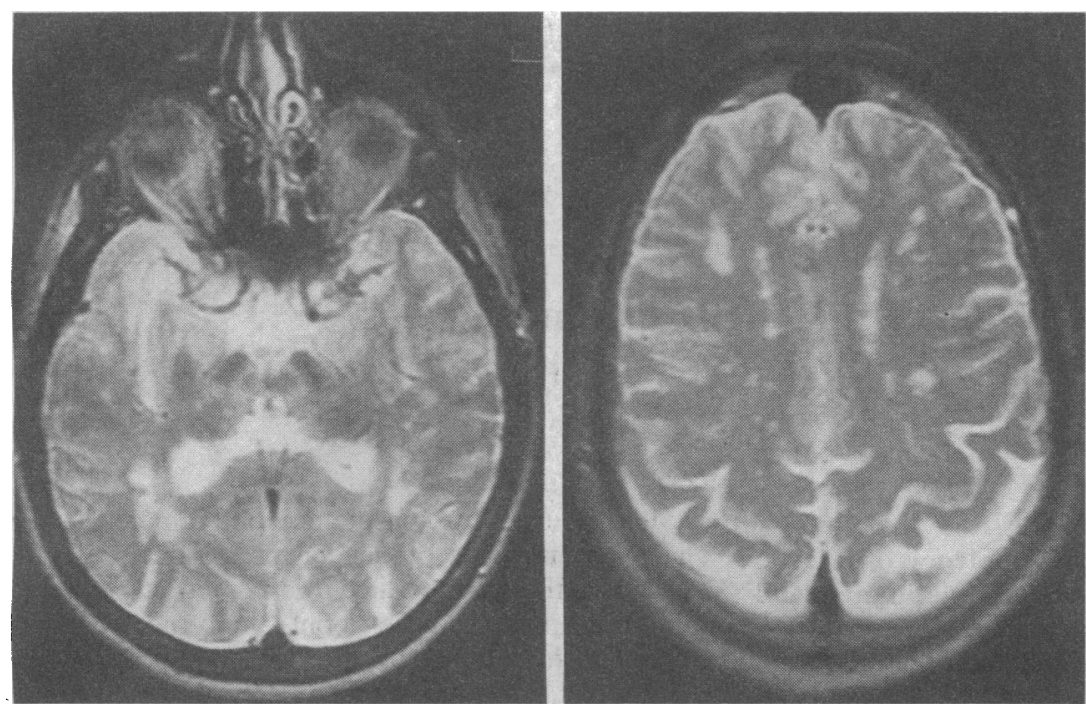

T2 weighted magnetic resonance images showing areas of high signal in periventricular white matter of both hemispheres

one admission he developed viral hepatitis $\mathrm{B}$. He was seronegative for HIV.

He underwent electroencephalography several times and computed tomography of the brain at least six times; all the scans were reported as normal. Magnetic resonance imaging of the brain several months before he developed hepatitis showed, in the T2 weighted sequence, areas of high signal disseminated in the white matter of both hemispheres (figure).

He usually vanished abruptly from hospital; to our knowledge no psychiatric follow up could ever be organised.

\section{Comment}

This patient showed behaviour typical of Munchausen's syndrome. ${ }^{1}$ The lack of reliable data in such patients' histories hampers the interpretation of genuine somatic abnormalities. In our case neuro- logical signs were always transitory and obviously factitious, but a magnetic resonance image of the brain showed patterns consistent with changes in the white matter of the hemispheres. In a 35 year old patient such changes are unusual, though not specific; they are associated with conditions including multiple sclerosis and infectious, toxic, or vascular insults. ${ }^{3}$

The abnormal magnetic resonance image gives rise to several hypotheses. Firstly, it may have been coincidental. Secondly, it may have been due to a brain disease responsible for the Munchausen's syndrome. Syndromes resembling Munchausen's syndrome have been reported in a few cases of organic disease. ${ }^{45}$ Thirdly, the abnormal pattern may have been the sequel of an acute illness in childhood or adolescence that predisposed to the adult behaviour. Children suffering from deprivation or parental rejection may remember admission to hospital for a physical illness as a gratifying experience. This may sometimes lead to a quest to be admitted repeatedly, evolving in Munchausen's syndrome. Finally, the abnormal pattern may have been due to self inflicted or iatrogenic insults to the brain. During all his documented admissions, however, the only iatrogenic accidents were episodes of hypoglycaemia, which were never severe enough to cause coma. We cannot exclude the possibility of other self induced or iatrogenic accidents.

This case illustrates the complexity of the interface between organic disorder and Munchausen's syndrome.

1 Asher R. Munchausen's syndrome. Lancet 1951;i:339-41.

2 Barker JC. The syndrome of hospital addiction (Munchausen syndrome). A report on the investigation of seven cases. Fournal of Mental Science 1962;108:167-82.

3 Holland BA. Diseases of white matter. In: Brant-Zawadski M, Norman D, eds Magnetic resonance imaging of the central nervous system. New York: Raven

4 Lidz T, Miller JM, Padget P, Stedem AFA. Muscular atrophy and pseudologia fantastica associated with islet cell adenoma of the pancreas. Archives of Neurology and Psychiatry 1949;62:304-13.

5 Brecker SJD, Trepte NJB. Myxoedematous Munchausen? Lancet 1990;335: 231.

(Accepted 13 February 1991)

\section{ONE HUNDRED YEARS AGO}

No one questions the harmfulness of juvenile tobacco smoking, and few of those who go about the world with their eyes open can doubt that the habit is markedly on the increase amongst the young, and especially so in towns. The eminently sensible remarks with which the Mayor of Manchester opened a conference recently held in that city contrast favourably with the somewhat extravagant assertions and suggestions made by several other speakers. Smoking in excess - always a relative term - is always bad for the smokers; but it is at least an open question whether the moderate indulgence in tobacco by adults is really more harmful than moderate indulgence in tea and coffee, to say nothing of alcohol. It may be true that, in the words of the President of the Anti-Narcotic League, " $10 \mathrm{lbs}$. of tobacco contains as much poison as would kill any person"; but the most extravagant smoker does not consume $10 \mathrm{lbs}$. of the "filthy weed"at a sitting, and it is quite probable that results equally startling would be achieved by the immediate consumption of the active principles of $10 \mathrm{lbs}$. of tea. On the other hand, an adult Kafir will beg for the "nicotine" which the English smoker diligently cleans out of his foul pipe, and the greedy delight with which he sucks up every trace of the brown poison is only a little more remarkable than the entire absence of any observable ill-effects, physical or otherwise. It is true that what the Kafir relishes is an effective and fatal poison to cobras and cats, but, as pointed out by a great apologist for tobacco, this is another proof that "we are not as tabbies are." Has the British nation "stunted its growth, blunted its nerves, and become altogether bad" since the spacious days of Sir Walter Raleigh? But on the subject of smoking by young and growing lads there can hardly be two opinions. It obviously stands in the same category with every other precocious indulgence which deadens or dissipates that vital energy which should be wholly available for the complete development and consolidation of the immature organism. We have not much sympathy, however, with the ardent enthusiasts who contend that the habit of smoking by the clergy is an almost insuperable obstacle to the improvement of youth, and who ask, "How can a father who smokes discourage smoking amongst his boys?" The obvious reply is, "By inculcating the habit of self-control in this as in other matters." If the principle implied in the question is a good one it is worthy of more general application; and if clergymen and fathers are to do nothing which their children should not do, the world would soon come to a standstill, and all true education would be abandoned for a disastrous levelling down. There is a field of good work open to the operations of the Anti-Tobacco League; but its members will needlessly cramp their opportunities if they begin by quite unnecessarily provoking the reasonable antagonism of the clergy and of fathers who might otherwise render them something even more effective than a benevolent neutrality. A good deal might probably be done by lessening the temptations which are nowadays abundantly present to the boys who want to seem men before they have outgrown their youth. There is a large class - most abundant in the great commercial and manufacturing centres - who can, perhaps, only be effectually reached by some such enactment as that nominally in force in the United States, which prohibits smoking in the streets by lads under 16 years of age. But in numberless cases frank confidence between father and son will accomplish more than legislation. (British Medical fournal 1891;i:770) 